2. Archazhnikova, L. G. (1998). Teoriya $i$ metodika muzykal'nogo vospitaniya. [Theory and methodology of musical education]. Moscow.

3. Kant, I. (2018). Krytyka chystoho razumu. [Criticism of the pure mind]. Moscow.

4. Lavrinenko, O. A. (2018). Pedahohichnyy dosvid: monitorynh ta perspektyvy. [Pedagogical experience: monitoring and perspectives]. Kyiv.

5. Oleksyuk, O. M. (2006). Muzychna pedahohika. [Musical pedagogy]. Kyiv.

6. Pedahohika vyshchoyi shkoly. (2009). [Pedagogika zhelayushchikh shkol]. Kyiv.

7. Rostovs'kyy, O. Ya. (2011). Teoriya $i$ metodyka muzychnoyi osvity. [Theory and methodology of music education]. Ternopil.

8. Rudnizka, O. P. (2005). Pedagogica: zagalna ta mistezka. [Pedagogy: general and artistic].Ternopil.

9. Ushinskiy, K. D. (1983). Teoretychni problemy vykhovannya i osvity. [Theoretical problems of education and education]. Kyiv.

10. Cherkasov, V. F. (2016). Teoriya $i$ metodyka muzychnoyi osvity. [Theory and methodology of music education]. Kyiv.

\section{ВІДОМОСТІ ПРО АВТОРА}

ЧЕРКАСОВ Володимир Федорович

доктор педагогічних наук, професор, завідувач кафедри музичного мистецтва i хореографії Центральноукраїнського державного педагогічного університету імені Володимира Винниченка.

Наукові інтереси: становлення і розвиток музично-педагогічної освіти в Україні та країнах Європейського Союзу.

\section{INFORMATION ABOUT THE AUTHOR}

CHERKASOV Volodymyr Fedorovich Doctor of Pedagogical Sciences, Professor Department of Musical Art and Choreography of Centralukrainian Volodimyr Vinnichenko Central Ukrainian State Pedagogical University.

Circle of scientific interests: formation and development of music-pedagogical education in Ukraine and European Union Countries.

Стаття надійшла до редакиії 15.01.2020 p.
УДК 37.091.12.011.3-80

DOI: $10.36550 / 2415-7988-2020-1-188-40-43$
ШАНДРУК Світлана Іванівна доктор педагогічних наук, професор, завідувач кафедри лінгводидактики та іноземних мов Центральноукраїнського державного педагогічного університету імені Володимира Винниченка ORCID:https://orcid.org/0000-0002-7472-4584 e-mail: sishandruk@ukr.net

\title{
FOREIGN LANGUAGE LEARNING TECHNOLOGY: COGNITIVE APPROACH
}

Formation and justification of the relevance of the problem. Knowledge of foreign language is the key to success in today's world, where communication with foreign language and the processing of vast amounts of information is becoming increasingly important.

The academic discipline of secondlanguage acquisition is a subdiscipline of applied linguistics. As well as the various branches of linguistics, second-language acquisition is also closely related to psychology, cognitive psychology, and education. To separate the academic discipline from the learning process itself, the terms second-language acquisition research, second-language studies, and secondlanguage acquisition studies are also used. Second-language acquisition research began as an interdisciplinary field [6]. The term acquisition was originally used to emphasize the subconscious nature of the learning process, but in recent years learning and acquisition have become largely synonymous.
Analysis of recent research and publications. Second-language acquisition can incorporate heritage language learning, but it does not usually incorporate bilingualism. Most second-language acquisition researchers (A. Benatty, S. Gass, R. Mitchell, F. Myles, E. Rod, L. Selinker, B. VanPatten and others) see bilingualism as being the end result of learning a language, not the process itself, and see the term as referring to native-like fluency. A complete theory of second-language acquisition must include both a property theory (of what the domain of knowledge is and how it is represented) and a transition theory (of how learners get from one knowledge state to another) (K. Gregg, N. Ellis and others). Thus second-language acquisition second-language acquisition is a subject of cognitive science par excellence (E. Bialystok, B. McLaughlin, M. Harrington, R. Schmidt and others) [3]. Writers in fields such as education and psychology, however, often use bilingualism loosely to refer to all forms of multilingualism . 
Internal factors affecting second-language acquisition are those which stem from the learner's own mind. Attempts to account for the internal mechanisms of second-language acquisition can be divided into three general strands: cognitive, sociocultural, and linguistic. These explanations are not all compatible, and often differ significantly.

The purpose of the article. Implementation of the cognitive approach to second language acquisition at university level is to be discussed in this article.

The main material of the study. Much modern research in second-language acquisition (R. Rueda, D. August, C. Goldenberg, J. Plass, D. Chun, R. Mayer, D. Leutner and others) has taken a cognitive approach [1]. Cognitive research is concerned with the mental processes involved in language acquisition, and how they can explain the nature of learners' language knowledge. This area of research is based in the more general area of cognitive science, and uses many concepts and models used in more general cognitive theories of learning. As such, cognitive theories view second-language acquisition as a special case of more general learning mechanisms in the brain. This puts them in direct contrast with linguistic theories, which posit that language acquisition uses a unique process different from other types of learning.

Cognitive approaches, including Functional linguistics (T. Bates, B. MacWhinney and others), Emergentism (J. Elman, B. MacWhinney and others), Cognitive linguistics (R. Langacker, D. Ungerer, R. Schmid and others), and Constructivist child language researchers (P. Brooks, C. Slobin, $\mathrm{M}$. Tomasello and others), view the linguistic sign as a set of mappings between phonological forms and conceptual meanings or communicative intentions [3]. They hold that simple associative learning mechanisms operating in and across the human systems for perception, motor-action and cognition as they are exposed to language data as part of a communicatively-rich human social environment by an organism eager to exploit the functionality of language are what drives the emergence of complex language representations.

The dominant model in cognitive approaches to second-language acquisition, and indeed in all second-language acquisition research, is the computational model [2]. The computational model involves three stages. In the first stage, learners retain certain features of the language input in short-term memory. Then, learners convert some of this intake into secondlanguage knowledge, which is stored in long- term memory. Finally, learners use this secondlanguage knowledge to produce spoken output. Cognitive theories attempt to codify both the nature of the mental representations of intake and language knowledge, and the mental processes which underlie these stages.

In the early days of second-language acquisition research interlanguage was seen as the basic representation of second-language knowledge; however, more recent research has taken a number of different approaches in characterizing the mental representation of language knowledge [1, p. 97-98]. There are theories that hypothesize that learner language is inherently variable, and there is the functionalist perspective that sees acquisition of language as intimately tied to the function it provides. Some researchers make the distinction between implicit and explicit language knowledge, and some between declarative and procedural language knowledge. There have also been approaches that argue for a dual-mode system in which some language knowledge is stored as rules, and other language knowledge as items.

The mental processes that underlie secondlanguage acquisition can be broken down into micro-processes and macro-processes. Microprocesses include attention; working memory; integration and restructuring, the process by which learners change their interlanguage systems; and monitoring, the conscious attending of learners to their own language output. Macroprocesses include the distinction between intentional learning and incidental learning; and also the distinction between explicit and implicit learning. Some of the notable cognitive theories of second-language acquisition include the nativization model, the multidimensional model and processability theory, emergentist models, the competition model, and skill-acquisition theories [6].

Other cognitive approaches have looked at learners' speech production, particularly learners' speech planning and communication strategies. Speech planning can have an effect on learners' spoken output, and research in this area has focused on how planning affects three aspects of speech: complexity, accuracy, and fluency. Of these three, planning effects on fluency has had the most research attention. Communication strategies are conscious strategies that learners employ to get around any instances of communication breakdown they may experience. Their effect on second-language acquisition is unclear, with some researchers claiming they help it, and others claiming the opposite [6]. 
Knowing other languages and understanding other cultures is a 21 st Century skill set for American students as they prepare to live and work in a global society. No matter what career students enter, they will be interacting with others around the world on a routine basis and doing business locally with those whose native language is not English [4].

According to the National Center for Education Statistics the number of students in the U.S. whose first language is not English has doubled over the last 20 years [2]. For these language-minority students who are learning a second language, the goal is to develop several core competencies that allow them to develop and maintain social relationships and communicate ideas.

To support these students' acquisition of a second language, researchers have identified two instructional approaches. First, proponents of the structural approach argue that drill and practice is the best way to learn grammar and vocabulary. With this approach, language is usually taught orally with an emphasis on the learner responding to spoken prompts. Second, the cognitive approach emphasizes how the learner interacts with language. An effort is made to make language acquisition a more active process. Instruction is based on activating prior knowledge and allowing the learner to build the cognitive skills required to understand, process, and interact with a language. Effective opportunities to learn a second language with the cognitive approach can be divided into three stages: a) comprehensible input, b) interaction, and c) comprehensible output.

Foreign language learning is much more a cognitive problem solving activity than a linguistic activity, overall. Studies have shown repeatedly that foreign language learning increases critical thinking skills, creativity, and flexibility of mind in young children. Students who are learning a foreign language out-score their non-foreign language learning peers in the verbal and, surprisingly to some, the math sections of standardized tests. This relationship between foreign language study and increased mathematical skill development, particularly in the area of problem solving, points once again to the fact that second language learning is more of a cognitive than linguistic activity. Learning a second language is an exercise in cognitive problem solving and the effects of second language instruction are directly transferable to the area of mathematical skill development.

The notion of «earlier is better» in language learning seems to be upheld by the fact that longer sequences of foreign language instruction seem to lead to better academic achievement [1, p. 46]. Because second language instruction provides students with better cognitive flexibility and creative thinking skills, it can offer gifted students the intellectual and developmental challenges they need and desire.

Immersion programs for older students are very effective as well. Depending on the age of the students, they may or may not develop native-like pronunciation and intonation. However, the older student already possesses an internalized grammar of the native language which is useful in learning a new language.

Regardless of age, immersion programs are effective because they use second language acquisition as the vehicle for learning the general education curriculum. This makes the content of the course inherently more interesting for the student and maximizes the instructional time by accomplishing two goals at once: language acquisition and content learning. Research on immersion programs show that when they are properly structured, they can be equally effective for younger and older students in developing oral proficiency and that all immersion students can achieve functional levels of bilingualism. However, children who start learning a second language before puberty seem to outperform, over the long run, older children and adults who begin the study of a second language after puberty and continue to study that language for the same number of years. Similarly, children who start learning a language at young ages have better opportunities to develop native pronunciation and intonation. But motivation is key that can help students to overcome some age-related factors in second language learning.

Immersion programs come the closest to providing students, young or old, with the intensive language experience they need to become proficient. In our opinion, it's the next best thing to study abroad. Not everyone has the means to study or live abroad, but immersion programs can do a lot to bring the language and culture to them. There are some excellent models in place in certain advantaged areas of the country. Everyone deserves the chance to become a citizen of the world in such a rich experience.

There is a difference between language acquisition and language learning. There are some individuals who seem to develop analytical thinking skills more readily than others, and this helps them in the learning of grammatical concepts [5]. However, that does not mean that only those students who are highly analytical should study a foreign language, as second language acquisition (listening and speaking) is a 
global process. Just as everyone needs to develop skills in a variety of curricular areas, everyone can benefit from learning a foreign language, whether it is because of the cognitive advantages or the exposure to and understanding of other cultures.

The cognitivists are convinced that learning depends upon perception and insight formation. The stages in the learning process [1, p. 57-64] can be characterized as the following:

1. The learner encountering a new situation recognizes it as a problem to be solved.

2. He analyses it and tries to identify the elements or components of the new situation.

3. He compares a new situation with those that he has previously encountered in an attempt to find out if it is similar or different.

4. The comparison suggests to him a plan or strategy for dealing with the new situation but the plan has to be tested.

5. The plan is tried out (tested): if it doesn't work, it is abandoned and alternative plan is involved and tried. If the plan works, it is stored in the system for use in the future.

Conclusions and prospects for further research of the direction. Effective instruction is promoted by a proper understanding of the problem domain and by instructors who evaluate their practices. Cognitive approaches to secondlanguage acquisition believe that a functionalist, usage-based model of language is the most appropriate analysis. This approach clearly dictates that in learning, as in theoretical analysis, language must not be separated from its function. Language and semantics are inextricable and thus we need functional, naturalistic, communicative situations for learning. In language instruction as in other educational domains, too much practice has been based on a naive operationalization of theory. Instructional practices need to be evaluated, assessed, and refined in everyday practice.

Among the promising areas of further research cognitive approaches to English for specific purposes at Bachelor Program level as part of reform of professional preparation of teachers in Ukraine deserve special attention.

\section{REFERENCES}

1. Chamot A. The CALLA Handbook/Anna Uhl Chamot, J. Michael O’Mally. NY: Brookline Books, 1994. $340 \mathrm{p}$.

2. Cognitive Benefits of Learning Languages [Електронний pecypc].

UKL:http://www.tip.duke.edu/node/866

3. Ellis N. Cognitive Approaches to SLA / N. Ellis // ARAL, 2012. Vol. XIX. P. 4-28

4. Jensen, E. Exact repetition as input enhancement in second language acquisition / E. Jensen, T. Vinther // Language Learning, 2003. Vol. 53(3). P. 373-428.

5. Laufer, B. What lexical information do L2 learners select in a CALL dictionary and how does it affect word retention? / B. Laufer, M. Hill // Language, Learning \& Technology, 2000. Vol. 3(2), P. 58-76.

6. Shandruk, S. Cognitive Approach to Language Learning at Elementary School Level / S. Shandruk // Academic Notes. No.122. Issue: Pedagogical Sciences. Kirovohrad: CSPU named after V.Vynnychenko, 2013. P. 412-419.

\section{ВІДОМОСТІ ПРО АВТОРА}

ШАНДРУК Світлана Іванівна - доктор педагогічних наук, професор, завідувач кафедри лінгводидактики та іноземних мов Центральноукраїнського державного педагогічного університету імені Володимира Винниченка.

Наукові інтереси: професійна освіта, компаративна педагогіка.

\section{INFORMATION ABOUT THE AUTHOR}

SHANDRUK Svitlana Ivanivna - Doctor of Pedagogical Sciences, Professor, Head of the Department of Linguodidactics and Foreign Languages of Volodymyr Vynnychenko Central Ukrainian State Pedagogical University.

Circle of scientific interests: professional education, comparative pedagogy.

Стаття надійшла до редакиії 11.01.2020 p. 